DOI: 10.31866/2617-2674.3.2.2020.217638

UDC 791.635-051+792

\title{
THE ACT OF IMPERSONATION IN THE CINEMA AND THE THEATRE
}

\author{
Mykhailo Barnych ${ }^{1 a}$, Halyna Rozhko ${ }^{2 a}$
}

${ }^{1}$ PhD in Study of Art, Associate Professor, Professor of the Television Journalism and Acting Department; e-mail: mngm@ua.fm; ORCID: 0000-0003-2482-5202

${ }_{2}^{2}$ Master's Student, Television Journalism and Acting Department; e-mail: rinetka@ukr.net; ORCID: 0000-0002-6297-7875

${ }^{a}$ Kyiv National University of Culture and Arts, Kyiv, Ukraine

\section{Keywords:}

an actor;

role in cinema

and theater;

creative process;

experience;

imagination;

psychotechnics

For citation:

\begin{abstract}
The purpose of this research is to identify and summarize the creative stages, components and sequence of impersonation in the cinema and the theatre. The research methodology is to apply the theoretical and analytical approach, in particular, while analyzing works and guidelines of theorists and practitioners of acting. The scientific novelty is an analysis of the sequence of the actor's activities on the role in the cinema and the theatre. The main creative stages of the actor's activities on the role are clarified. Based on the analysis of techniques and methods of impersonation, the relationship of the structural components that form the actor's image in the cinema and the theatre is determined. Conclusions. The constituent elements of the act impersonation and its constituent elements are analyzed in the article. The acting creative process is divided into two main stages: preparation for the role-playing and the role-playing itself. The creative stage of preparation for the role-playing includes analysis and formation of the personality and characteristics of the particularities of the character, action analysis and play in the imagination. The second creative stage is the roleplaying in public, which means the creation by the actor of an act of experience based on external and internal role image, previously created independently and with the director. Structural components that form an actor's personality are elaborated in detail. Gradual plan for impersonation has been developed and defined. The factors that influence successful role-playing are summarized.
\end{abstract}

Barnych, M. and Rozhko, H. (2020). The act of impersonation in the cinema and the theatre. Bulletin of Kyiv National University of Culture and Arts. Series in Audiovisual Arts and Production, 3(2), pp.182-189.

\section{Problem Statement}

The process of impersonation is one of the key stages of an actor's success. The versatility of fantasy and imagination is the main factor influencing the brightness and unusualness of the image. However, each artist has his/her own natural 
inclinations and certain individual ways of impersonation in the cinema and the theater. Observations of the actors' playing show that worthy role-playing models are quite rare among young actors and more often among experienced one. The individual way and method of impersonation for each artist is different, but all without exception are based on certain general principles, which are considered in the article.

\section{Recent research and publications analysis}

Many theoretical works have been written on the issue of successful performance and impersonation. In particular, Zakhava B.Ye. (1973) in his book defines a detailed sequence of an internal and external "life" creation. Instead, Vakhtangov Ye.B., as it was noted by Ivanov V.V. (2011), defines certain focuses and guidelines for the development of the actor's personality. Aspects of determining acting talent are covered by NemyrovychDanchenko V.I. (1952). Kristi G.V. (1968) defines what elements of impersonation the actor is necessary first of all to concentrate on.

One of the latest studies in the field of acting was conducted by coauthor Barnych M.M. (2018). However, the basic guidelines for achieving a successful impersonation are defined by Stanislavskyi K.S. (2015).

\section{Purpose of the article}

The purpose of the research is to identify and summarize the creative stages, components and sequence of impersonation in the cinema and the theater.

\section{Main research material}

The main criterion of the actor's work on the role is to reveal the inner world of the character, the world of his soul and experiences. In fact, it is the ability to reproduce the psycho-emotional state of the character that determines the level of the actor's skills. NemyrovychDanchenko V.I. (1952, p.216) marked the following: "Can a theatrical image be created by an actor who has not found the great simplicity to which art goes? Can there any creation take place if the actor develops the role and does not live it? This question closely merges with the question of simplicity. How to create it? There is such a phenomenon - the fame of an actor, his/her reputation is not based on the number of roles he/she played, but only on the number of roles he/she impersonated. Therefore, the task is to determine what it means for an actor to create an image of the character.

First of all, let's ask a question that covers the very concept of an "image". Stanislavskyi K.S., according to the memoirs of his contemporary NemyrovychDanchenko V.I. (1952, p.216), took into account only well-created and welldeveloped roles: "The ways to create a role are extremely deep. The whole tension of Stanislavskyi's work was reduced to the fact that he recognized the role impersonated on the stage only".

After all, an image is an artistic, synthesized, bright, audiovisual work that must express the character depicted by the author both independently and in the context of a film or a play. This is a character that the viewer sees on the screen or at the stage. There are dramatic characters, thanks to which the author can convey his/her own experiences, or the 
third person. There are comic one through which the author conveys his/her own satire on the behaviour of people under certain circumstances. "The secret of art is to turn fiction into a beautiful artistic truth", - said Stanislavskyi K.S. $(2015$, p.84).

It is worth noting that the character is not just an actor who plays, but a clearly defined artistic image, through which the author tries to convey his/her thoughts and views, which in acting terminology has a clear definition - the overriding task. To define an overriding task, an actor must first understand his/her character and determine the grain of the image. "To start working on a role, the actor must clearly and distinctly answer the question: why will he/she play this role in this play? - that is, to define the acting overriding task", Zakhava B.Ye. (1973, p.231) notes.

The artist's work on the role, according to Stanislavskyi K.S. (2015, p.78), begins with the first reading of the play, with the first acquaintance with it. Through introspection, which helps to know the attitude of the artist and his/her vivid feelings to everything that happens in the play or script, through the revival of the conditions or proposed circumstances of the character's life by personal creative imagination.

Imagination is one of the main links in the art of acting. Based on the role analysis, ideas and rehearsals the entire life story of the character, which is activated during the role with the help of acting techniques, is stored in the emotional memory of an actor. Emotional memory includes not only the imagined, but also the meaningful, analyzed life of the character. Everything heard, seen, understood by the actor is stored in this memory compartment. It should be noted that the quality of the material analyzed is proportional to the intelligence and personal abilities of the actor. Zakhava B. Ye. (1973, p.231) noted: "Personal experience of an actor and his/ her direct observations are the best source of knowledge... It is bad if the knowledge of life of the artist is only abstract. The richness of certain observations is necessary condition for true knowledge of life, necessary condition for artistic creativity".

According to Zakhava B. Ye. (1973, p.230), an actor has ninety percent of time spent on the role to devote to extracurricular (home) activities. "I think the actor will do the right thing if he/she starts his/her homework on the role by hiding its copy in a desk drawer, so as not to touch it at all for a while. Let the first stage of his homework on the role be the study of life itself".

Based on the observations and practical experience of working on the role, it can be argued that first of all it is necessary to identify "shock" emotional places in each piece of the role. According to the work of Zakhava B. Ye. (1973, p.236), the next element of impersonation is to invent a biography of the character in order for it to be engraved in the minds of an actor on a par with his/her own biography.

It should be noted that in the artist's own emotional memory, it is necessary to find familiar feelings that come, for example, from the betrayal of a friend, loss of a father, unrequited love, and so on. However, it is necessary to test them in the imagination through the character, but not through the imagination of relatives and loved ones. Kristi G. V. notes: "The main secret of reception: experiences are born independently, reflectively, according to the law of body and soul connection" (1968, p.308).

"The line of thought, the line of action and the line of imagination must be pre- 
designed by the actor at home, outside of rehearsals. Then the rehearsals will be creative. In the process of creative communication with partners involuntarily, the fourth line of stage life is born - the line of feelings" (Zakhava, 1973, p.230).

It is worth to note that the so-called "film of figurative visions" is formed in the artist's imagination through the detailed development and creative feeling of the actions written in the role. This concept is introduced by Zakhava B. Ye. (1973, p.245). It should be noted that an important component of work on the role in the imagination is the game "about yourself", because the internal processes are excited (thoughts, fantasy, imagination are excited). Let's define that thus the actor's psyche prepares for rehearsal work.

Famous director Vakhtangov Ye. B., according to the records of Ivanov V. V. (2011, p.449), noted the important action of the subconscious in creating an image: "Consciousness never creates anything. Unconsciousness creates. In the realm of the unconscious, in addition to its independent ability to choose without the consciousness, material for creativity can be sent through consciousness". We should note that in the intervals between rehearsals in the unconscious the creative work of processing the resulting material takes place. We determine that rehearsal work is productive when material is sought or given to develop a role and create an image in the cinema and the theater.

We should note that another important element of acting is improvisation. The main principle of playing in the cinema and the theater is the play "here and now", because it is a spatially temporal art. Ivanov V. V. (2011, p.454) notes that Vakhtangov Ye. B. also noted the importance of improvisation: "I would like the actors to improvise the whole play. After all, they know who they are, what they have to do with other actors, and they have the same thoughts and directions, they want the same, so why can't they live, that is, act. Do not stamp anything. Each rehearsal is a new rehearsal".

It should be noted that the biggest problem of acting at all times was and remains the so-called "stamping". "I don't want the actor to always play one part of his/her role just as strongly or equally low. I want the actors to naturally have those feelings today and to the extent of the excitement in which he/she will be true today," says Vakhtangov Ye. B., that was noted by Ivanov V.V. (2011, p.452). That is, each rehearsal is unique and the worst is when the actor wants to repeat yesterday's luck, when he/she is preparing for a strong place. It is worth to note that strong places are the actor's self-expression.

Another important phenomenon of successful role-playing is the "contagiousness" of the actor, which is distinguished by NemyrovychDanchenko V. I. (1952, pp.214-215): "What is the "contagion" of the actor? In fact, "contagion" is a talent. One acting personality has "contagion", like dramatic experiences, the other - comic one". That is, we determine that there are actors need to think about the character's experiences as these experiences immediately infect the audience or the recipient. Instead, another individual, more often a woman, bursts into tears, and the viewer remains cold. Or the actor said only half a phrase with a comic meaning, even just looked before saying that phrase - and the viewer is already smiling. Another tries his/her best to make laugh - and doesn't succeed. Thanks to these examples, you can immediately determine and identify 
a talented artist - dramatic, lyrical and comic one. The problem of talent is noticed by Nemyrovych-Danchenko V.I. (1952, pp.214-215): "Is it possible to teach this, or is it necessary to be born with such talent? Maybe not to teach, but to instil, educate, maybe even, again, "inspire" with it? All that helps "contagion", its strength and brightness are external data, namely: voice, face, eyes, and gesture".

It is due to external data that elements of external characteristic are created. Zakhava B. Ye. (1973, p.246) noted that the law applies to the creation of the characteristic features of the character: from internal to external. However, according to our observations, we can note that there is a group of characteristic elements that do not obey this law. These include such external features and properties that do not depend on the inner life of man and are able to independently imprint on the inner life. We can note that in addition to the features directly indicated in a play or a script, an actor adds fantasies to impersonation, which complicates independent work. We note that national and local characteristics are important because they are reflected in language and movements and do not depend on the inner life, but on the contrary have the ability to influence it. These elements, we note, must be taken into account from the initial stage of work.

It is to emphasize that in order for the "fatness" to grow into the actor's body, organically merge with him, you must first learn to be fat without any "fatness": to master behaviour of a certain person, creatively - please do not laugh: creatively! - to grow a belly" (Zakhava, 1973, p.247). It is investigated that the example given by Zakhava $\mathrm{B}$. Ye. is the case when you need to grow a "hump", feel pain in the body or find behaviour of a person with ugly facial features. It should be noted that rehearsals are not enough for the success of this work - you need to work at home.

It is to emphasize that it is important for an actor to learn to wear a costume. Based on practical experience, we determine that exercise will bring success in this role element, during which the actor, dressed in ordinary everyday clothes, behaves as if he/she wears a suit.

Another hint for the successful impersonation is found at Ivanov V.V. (2011, p.452), while Vakhtangov Ye. B. notes: "If an actor understands the image he/she needs to play well, and understands that the steps indicated by the author, are logical and cannot be different, if then the actor is tempted to mentally be in these conditions, if he/she loves (without compassion) something in a play and a roles, if at the end, he/she will be sure of what this person of the play is sure of, and will feel the need to spend few hours in the "atmosphere of Rosmersholm" and prepare for the holiday that creativity gives - he/ she will be reincarnated and he/she will not lose his/her personality in anything". Analysis of this statement gives us reason to determine that an important element of successful role creation is the artist's love for it and for him-/herself in the role. Based on observations, we note that love is a lever that inspires the character created by the artist. According to NemyrovychDanchenko V. I. sincerity, individuality and theatricality are three, perhaps, the most important phenomena in acting (1952, pp.214-215).

"Exercise in life" should help the actor to complete the work on the role, says Zakhava B. Ye. (1973, p.251): "They are that the artist, being in character uses every 
opportunity to talk to someone in real life. At the same time, the partner should not suspect it". Exploring this exercise, we noted its great benefits. Because in this way the artist can verify the correctness of the work done, find mistakes and feel not only in the proposed circumstances, but also the proposed image in life.

Based on the above, we can say that the actor's image is an independent work of art. You can suggest and offer many means of its creation, but if the actor does not work on him-/herself, does not finish working properly - all his/her efforts to succeed will be in vain. Vakhtangov Ye. B. emphasized, as noted by Ivanov V.V. (2011, p.454): "It is not necessary to show on the stage by one's own behaviour: here I am according to my plan... I would like all performers not to do anything theatrical in the morning on the day of the performance and not to be called to rehearsals of other performances. Also, that the performance was held no more than once a week. That the performers would love this performance and would feel the holiday when its day comes". After all, creative well-being in the role is one of the important artistic components of acting.

\section{Conclusions}

The actor's work on the role is divided into two main stages. Based on the analysis of the role, ideas and rehearsals the entire life story of the character is stored in the emotional memory of the actor. Due to the detailed development and creative feeling of the actions written in the role, the so-called "film of figurative visions" is formed in the artist's imagination. During the performance of the role with the help of technique, the actor evokes the feelings experienced in the imagination and at rehearsals. At this stage, important elements of the actor's skill are artistry and the ability to improvise. Thus, the first creative stage includes analysis and rehearsal of the role with the director (formation of the character and its characteristic features, action analysis, mise-en-scène, etc.) and independent preparation of the role by the actor (studying the text, playing the role and experiencing this playing in the imagination, etc.). The second creative stage is the public performance of the role. This stage is called creative because the performance of the role in public conditions is the creation by the actor, inside his/her person, of an act of experience according to the external and internal drawing of the role created in advance independently and with the director.

The main criterion for creating an image for the actor as an artist is to reveal the inner world of the character, the world of his/her soul and experiences. The line of thought, the line of action and the line of imagination are pre-developed by an actor at home, outside of rehearsal.

An important element of acting skills is the personal experience of the actor and his/her direct observations.

Identified and generalized creative stages, components and sequence of impersonation in the cinema and the theater will help not only beginners but also professionals to review and understand their own skills and abilities.

\section{REFERENCES}

Barnych, M.M., 2018. Psykhotekhnika aktora. Maister-klas [Psychotechnics of the actor. Master class]. Kyiv: Pinzel. 
Ivanov, V.V., 2011. Evgenii Vakhtangov. Dokumenty i svidetelstva [Evgeny Vakhtangov. Documents and certificates]. Moscow: Indrik. Vol. 1.

Kristi, G.V., 1968. Vospitanie aktera shkoly Stanislavskogo [Education of the actor of the Stanislavsky school]. Moscow: Prosveshchenie.

Nemirovich-Danchenko, V.I., 1952. Teatralnoe nasledie [Theatrical heritage]. Moscow: Iskusstvo. Vol. 1.

Stanislavskii, K.S., 2015. Iskusstvo predstavleniia [The art of presentation]. St. Petersburg: Azbuka.

Zakhava, B.E., 1973. Masterstvo aktera i rezhissera [The skill of the actor and director]. 3nd ed. Moscow: Prosveshchenie.

\title{
АКТ СТВОРЕННЯ РОЛІ В КІНЕМАТОГРАФІ ТА ТЕАТРІ
}

\author{
Михайло Барничㅁ, Галина Рожкоª \\ ${ }^{1}$ кандидат мистецтвознавства, доцент, професор кафедри тележурналістики та майстерності актора; \\ e-mail:mngm@ua.fm; ORCID: 0000-0003-2482-5202 \\ ${ }^{2}$ магістрант кафедри тележурналістики та майстерності актора; \\ e-mail: rinetka@ukr.net; ORCID: 0000-0002-6297-7875

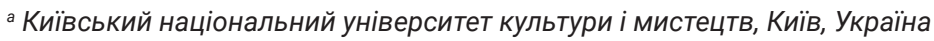

\section{Анотація}

Мета дослідження - визначити та узагальнити творчі етапи, складові частини та послідовність творення ролі в кінематографі та театрі. Методологія дослідження полягає у застосуванні теоретико-аналітичного методу, зокрема в аналізі праць та методик теоретиків і практиків акторського мистецтва. Наукова новизна. Здійснено аналіз послідовності праці актора над роллю в кінематографі та театрі. З'ясовано основні творчі етапи праці актора над роллю. На основі аналізу технік та методик створення ролі визначено взаємозв'язок структурних компонентів, що формують акторський образ в кінематографі та театрі. Висновки. У статті проаналізовано складові елементи та послідовність акту творення ролі. Встановлено, що акторський творчий процес поділяється на два основні етапи: підготовка до виконання ролі та виконання ролі. Творчий етап підготовки ролі охоплює аналіз і формування характеру та характерних рис образу, дійовий аналіз і гру в уяві. Другий творчий етап - це виконання ролі в публічних умовах, який передбачає творення актором акту переживання за заздалегідь створеним самостійно та з режисером зовнішнім та внутрішнім малюнком ролі. Детально опрацьовані структурні компоненти, які формують акторську особистість. Опрацьований та визначений поетапний план творення ролі. Узагальнено чинники, які впливають на успішне виконання ролі.

Ключові слова: актор; роль в кінематографі та театрі; творчий процес; переживання; уява; психотехніка 


\title{
АКТ СОЗДАНИЯ РОЛИ В КИНЕМАТОГРАФЕ И ТЕАТРЕ
}

\author{
Михаил Барнич19, Галина Рожко ${ }^{2 a}$ \\ ${ }^{1}$ кандидат искусствоведения, доцент, профессор кафедры тележурналистики и мастерства актера; \\ e-mail: mngm@ua.fm; ORCID: 0000-0003-2482-5202 \\ ${ }^{2}$ магистрант кафедры тележурналистики и мастерства актера; \\ e-mail: rinetka@ukr.net; ORCID: 0000-0002-6297-7875

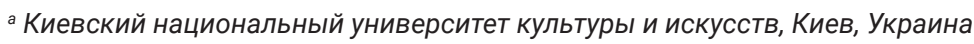

\begin{abstract}
Аннотация
Цель исследования - определить и обобщить творческие этапы, составные части и последовательность создания роли в кинематографе и театре. Методология исследования заключается в применении теоретико-аналитического метода, который предполагает анализ работ и методик теоретиков и практиков актерского искусства. Научная новизна. Осуществлен анализ последовательности работы актера над ролью в кинематографе и театре. Выяснены основные творческие этапы работы актера над ролью. На основе анализа техник и методик создания роли определенавзаимосвязь структурных компонентов, формирующихактерский образ в кинематографе и театре. Выводы. В статье проанализированы составляющие элементы и последовательность акта творения роли. Установлено, что актерский творческий процесс делится на два основных этапа: подготовка к выполнению роли и выполнение роли. Творческий этап подготовки роли охватывает анализ и формирование характера и характерных черт образа, действенный анализ и игру в воображении. Второй творческий этап - это выполнение роли в публичных условиях, который предусматривает создание актером акта переживания по заранее созданным самостоятельно и с режиссером внешним и внутренним рисунком роли. Детально проработанные структурные компоненты, которые формируют актерскую личность. Проработан и определен поэтапный план создания роли. Обобщены факторы, которые влияют на успешное выполнение роли.
\end{abstract}

Ключевые слова: актер; роль в кинематографе и театре; творческий процесс; переживание; воображение; психотехника 